\title{
A Literature Analysis of “Kering” By Iwan Simatupang
}

\author{
Rosmani Sianipar \\ Fotografi, Universitas Pasundan, Bandung, 40153, Indonesia \\ sianiparrosi@gmail.com \\ Abstract
}

Iwan Simatupang the great writer was born on January 18, 1928. Lots of his works have been translated into various languages, while the demand for reprints continues to increase. Iwan Simatupang's "Kering" is not only in a physical sense but is more contemplative in nature. With the adventures carried out, he describes how the actors are afflicted with psychological, spiritual, ideas, and ready to be swallowed by termites so that it becomes pathetic. Iwan, in channelling his ideas and thoughts is by the understanding of the philosophers he admires, namely existentialist philosophers. Iwan can also be called a nihilist. He negates all old values and confirms standard values. He tried to overcome something he felt was an obstacle in the creation of his writing. The flow of thoughts he emits in a firm, yet artistic form. This is most evident in the novel 'Kering'. He ignores the rules, neither in his life nor in formulating his thoughts. If people want to characterize the nature of his mind and wisdom, it is fierce, like a sailboat hit by the waves of the ocean.

Keywords: irrationalism, parallelism, philosophy of existentialism,

\section{Introduction}

Looking at the repertoire of literary arts in Indonesia, there are several writers whose works have quality and can provide catharsis for their readers. One of them is the figure of Iwan Simatupang. Prolific writers who do not have good access to publications.

Iwan Simatupang the great writer was born on January 18, 1928. His perspectives are interesting to observe. Quite a lot of his works have been translated into various languages, while the demand for reprints continues to increase. Therefore, this famous writer who has received an international award was deliberately appointed as a study material. In the opinion of the author, Iwan Simatupang's critical thinking is interesting to observe because it contains artistic and philosophical values. As reported in the media "Siasat Baru" (XII/66, 30 December), Iwan Simatupang has been writing essays since 1953 at the age of 25. Only then, this famous writer actively write short stories and it was published for the first time in 1959 entitled Lebih Hitam dari Hitam after he returned from Amsterdam, Leiden, and Paris. However, his first literary activity was when he wrote poetry, then his name was published in the cultural 
rubric Gelanggang, Buah Tangan column, and the weekly siasat magazine led by Soedjatmoko and the Managing Editor of Gadis Rondonuwu or Gadis Rasid.

Following are Iwan Simatupang's poems, including the poem Ada Duka Cita di Gurun published by Siasat, VI/270, o6 July 1952. The poem Ada Dewa Kematian Tuhan - to commemorate the 10oth year of Nietzsche's death, was published in Siasat magazine, VI/285, 02 October 1952 page 21. Other poems were published in Zenith magazine, III/9, 1953 and Mimbar Indonesia, VII /26, 1953. Meanwhile, he continued his essay writing activity until the end of his life on August 14, 1970.

The first essay was published in the Mimbar Indonesia, number VII/30, 1953, number 38, 1953, and then spread to other magazines such as Siasat and Gajah Mada, Yogyakarta. After that, after dropping out of school from the Faculty of Medicine in Surabaya, Iwan Simatupang was later listed as a member of the Editorial Board of Siasat magazine, Jakarta. But not long after that, on December 5, 1954, he decided to leave because he decided to go to Amsterdam, to study on a STICUSA (Stchting voor

Culturele

Samenwerking) scholarship.

In addition to writing short stories and essays, Iwan Simatupang also wrote several dramas plays, including Buah Delima and Bujur Sangkar in 1957 and Petang di Taman in 1958. It turns out that his passion for writing plays is closely related to one of his activities in Amsterdam, where in addition to studying Anthropology, Sociology he also pursued acting.

On December 29, 1977, his novel entitled Ziarah won the ASEAN literature in Bangkok (Encyclopedia, 1984, p. 3177). Before he died on August 14, 1970, Iwan Simatupang lived at the Salak Hotel, Bogor, and lastly, he settled on Jalan Kencana, Jakarta.

1.1 Humans in Iwan Simatupang's Short Stories

His short story works were successively published in Siasat Baru 1960, Star Weekly 1960 - 1962, illustrating how have fun Iwan was in writing short stories. Iwan seems 
to find a way to shed, release a cry or "lyric cry" - borrowing the term a lyric cry from Frank O'Connor - in dealing with questions about loneliness and the purpose of human life.

Since the 1959 story titled Lebih Hitam dari Hitam, the human characters shown are very veiled. Man trapped in the web of his consciousness, pathos with the incomprehension of life he faces. Borrowing Iwan's term in the short story Kereta Api Lewat di Jauhan, Siasat Baru, XIV/666, March 16, 1960

- the humans are almost human.

After insisting wrote short stories during that period, his creative combination was marked by writing a novel. The novel Ziarah, written around mid-October 1960 and finished on November 10, 1960. Merahnya Merah was written from March 18, 1961, to September o9, 1961. Kering was written around 1961.

Compared to the humans in Iwan's short stories, in his novels, Iwan's humans seems to be more total. Borrowing the term from Frank O'Connor's, in Iwan's short stories, the humans are like guerrilla fighters who emerge from the darkness of the forest. Therefore, humans in Iwan's novels appear more total as soldiers on the battlefield.

Iwan's human footprints since the short story - Lebih Hitam dari Hitam, 1959, Monolog Simpang Jalan, 1960; Kereta Api Lewat di Jauhan, 1960; Patates Frites, 1960; Tunggu Aku di Pojok Jalan Itu, 1961; Tegak Lurus dengan Langit, 1962, until other novels can be explored thematically. Humans in Iwan's works are practical humans as opposed to existing humans (Hazel E. Barnes: Humanistic Existentialism, Literature of Possibility, 1959). His awareness of irrationalism, awareness of the value of life, it is not clear which meanings, and reality are so that humans are biased who lose in trying to understand what the essence of life is.

In Iwan's short stories or novels, almost always the image of similar human, namely a problematic human whose history, identity, and goals are always questioned. A midfielder who mysteriously disappeared, died by suicide - hit by the element of 
incomprehension of life. Readers do not seem to be given a place to rejoice and enjoy happiness. Until last Iwan's novel for youth reading, entitled Kooong, 1968, depicts the similar human as the one presented in the short story Monolog Simpang Jalan, 1960. For example, the story is about a child who committed suicide because he didn't know what to do anymore and the character's father went on an adventure on lost keys of the senseless suicides. It seems that it is closely related to the conditions at that time. The frenzy of political and economic life in the country and the death of the only magazine that existed at that time - Siasat. This happened before the G 30S/PKI attempted power struggle in 1965.

In 1968-1970, Iwan's short stories were still sometimes found with the character of 'Potret Suasana' - Warta Harian, led by Iwan Simatupang. The length of the story is adjusted to the available Daily News column. The content is light, joking but sometimes touching. The theme is also interesting. Play around with the small people. Pretending to be critical and tragic at the same time.
The attachment to the available letter columns, of course, requires the improvisation of the writer who sometimes has to lengthen or shorten the story according to the needs of the column. This impression appears when, for example, reading, Tak Semua Tanya Punya Jawab (Warta Harian, 28 October 1968).

Reading the story of 'Potret Suasana', Iwan reminded people on the column entitled "Dari Celah-celah Perhatian Tuan" on page 13 of the deceased's Strategy magazine. Incidentally, it is also filled with one or two writings of Iwan using his real name Iwan Maratua Dongan Simatupang born in Sibolga, North Sumatra, on January 18, 1928. The difference here, Siasat is more oriented towards community portraits from a juridical perspective, meanwhile Warta Harian is more like a fictional story and pretense literature.

The question arises, how is the quality of Iwan's short stories, who has entered the Department of Western Philosophy at the Sorbonne University, Paris. Both in the form of the first written form either in the form of the second form for a 
newspaper column - related to the reason from the author later.

The answer about quality, usually the plus-minus depending on the needs of the readers at the time. Personally, author says very well because Iwan's themes are very relevant to current conditions. Can be used as a solution in achieving catharsis after reading Iwan's stories. But universally it can be concluded that the plus quality of Iwan's stories if someone has decided, they get pleasure and reflection of life and benefits from the story. Meanwhile, the minus, if the type of reader is concerned with the taste of their tongue alone. The analogy is that, if someone has a sore tongue or a toothache, surely any kind of food will not taste good.

Theoretically, short stories can usually be said to be high quality, if they can inspire thoughts, stimulate pleasure, and enrich our lives. According to Maurice McNamee, James E. Cronnin, and Joseph A. Rogers in their book Literary Types and Themes, p. 13, 1997, it is said that the greater the level of stimulus given by one short story, the more qualified it is from other short stories.

Iwan Simatupang's works are considered strange, avant-garde. It is also quite objective in reviewing the issue of whether or not the quality is good in the work given to the reader. As he wrote in a newspaper, October 13, 1969, addressed to HB. Jassin (always addressed by the nickname Hans), reads: "The registration of these sensory impressions, is it also called literature? Proust, Kafka, Ludwig Kleiges, Strindberg to Nietzsche, a summing up of biological pulses, imbued with cosmological comments. And we call all of the great literature, great philosophy."

The problem should be returned to the reader of the short story itself. For example, after the reader has finished reading the entire short story, he or she will immediately feel what the answer is that comes out of his senses and mind. Where are the pluses and minuses?

This is the description of Iwan Simatupang who has been a teacher, journalist, and writer of essays, short stories, poetry, drama, and novels. Iwan Simatupang emerged with the 
emergence of the 'existentialism fever' in Indonesia. Therefore, his work is often considered difficult, soaring, and full of philosophical reflections. Especially the drama characters are considered to represent the author's character who is always contemplating with a desire to philosophize. For example, the play Taman very poetically tells the tragedy of language. Iwan's plays are interesting, others are $R T-O / R W$ o, Cactus dan Kemerdekaan.

\section{The Meaning of Existentialist Philosophy}

Before entering the work 'Kering', it is important that we briefly discuss existentialist philosophy, in fact, the philosophical understanding that Iwan Simatupang is involved in. This flow emerged around 1940. This philosophy suggests that humans are not determined by social, biological, hereditary, fate, and God factors. Man is determined by himself. Humans have free will, therefore they are responsible for their freedom. Therefore, the human condition is largely determined by what he does.

Human cannot choose or reject other forces outside himself. Man must do so he exists. This flow emphasizes the basic elements that exist in humans, namely consciousness. The subconscious and its irrationality. Life is constantly flowing and must be filled with actions. Man is a collection of his actions. So actually existentialism is not a literary school but a philosophical school. So even the technique of this flow does not have special characteristics. This flow is very popular in Indonesia.

\section{Kering by Iwan Simatupang}

"Kering" by Iwan Simatupang tells the story of a bright-brained student. This student, of his own free will, left college and went transmigrating. Then when the drought and brought misery to the entire population, he was finally thrown into city life. However, after experiencing various life problems, he built the city of his dreams, namely the city of transmigration. 
Through the dramatic story of a prolonged drought, Iwan tries to build an atmosphere of dry earth. Criticizing those who exploit nuclear power for war purposes, where human experimentation has caused the seasons to become irregular - is aimed at people living in cities who have been tempted to commit various cunning to accumulate worldly treasures. That said, humans are objects too. But not only the object, but also the subject. Man sees, he understands, places himself against everything that must be faced. He gives place and gives meaning. Thus, he also lives in reality (Drijarkara, 1999:6).

Thus, Iwan realized himself so that he could place our character in such awareness. Although our character is judged to be insane, a strange human being, our character is aware of what he is doing. Our character realizes himself as an object as well as a subject being. This is in stark contrast to what we know as the characters we meet in our current real life. They are called characters but what they do cannot be accounted for. All of a sudden, we have seen them go to jail, through television media. The human irony today. His life is increasingly become secular.

Iwan tries to understand the reality of his consciousness, as he feels something happening in his surroundings. The idea, the image in his mind, is poured out frankly regardless of one's social status. We can see this in the dialogue that occurs between fellow transmigrants. The character and his friends laughed. But only then will they know how broad the meaning of transmigration is. How difficult it is for developing countries to do this. Transmigrate like Vietnam with Dien Bien Phu for adventurers who register for the Legiun Asing. Win or be heroes, they still have no names. Dead, not necessarily they are buried. It is the same with the condition of the Palestinian army and the Israeli army now. Yes, for those soldiers, win and lose, they won't have names anyway. Back to a tragic story. They are only victims of the Palestinian rulers and the Israeli rulers. The ruler does not know how heavy the 
impact of the war will be. A ruler who does not know himself.

Our character is happy because he has found in the Glasses, a ruin of ideals that turns into a fierce adventure challenging the future. He was sure, The Glasses would be his best friend.

- And Brother? he asked to the Short Fat, with the look of a landlord.

- I'm a gambler. And the locksmith. One day I embezzled the company's money, where I was the cashier. I confess frankly. Therefore, the trial proceeded very smoothly. Judges and prosecutors are happy. I was sentenced to 2 years. I received the cash, without having to think about it. Last week I was released from prison, and now...

- ... You become a spontaneous transmigrant.

- More or less.

They laughed. Our character is also sure that the Short Fat will be his best friend.

- And Sir? Ask our character to a Hajj. He didn't answer. He scratched his grey head. Then, he went to the trellis of the ship's deck. From a friend from the hajj village who joined the group, they learned that this Hajj was involved in fraud regarding the hajj quota.

- Our character is silent. In his heart: Hopefully, he can also be a friend.

Iwan Simatupang describes how he was convinced that he could befriend two beings with such backgrounds.
On another occasion, he also had doubts as to whether Pak Haji could become his best friend. He was only hopeful. It seems that Iwan has realized that the Glasses and the Short Fat have a sporty life, unlike Pak Haji.

Iwan's sentences are short and dense, giving meaning to the reader. Thus, try to invite readers to also have a short and solid mindset. Iwan's efficiency in words stems from his education in philosophy. Therefore, he is adept at placing words that give a very broad meaning. This means that Iwan also uses asyndeton and parallelism (L. Pasaribu, Kesusastraan dan Gaya Bahasa Indonesia, P. Siantar, 1998, pp. 6974). The sentences are short, and the use of repeated words does not make the reader bored. Readers are led to stay focused on Iwan's writings. In addition, several of Iwan's works have the value of deep reflection. $\mathrm{He}$ poured many of his ideas into his writings which also became his philosophy of life.

The names of the characters used by iwan use a metonymic style (L. Pasaribu, Kesusastraan dan Gaya 
Bahasa Indonesia, P. Siantar, 1998, p. 73), such as the glasses and the fat and our character. This gives a new nuance to our literary repertoire, unlike what is commonly used by writers in general.

Iwan also composes his words using a climax language style, where the sequence of his words is increasing over time. One of the excerpts: Diperhatikannya sejenak wajah mereka yang tegak terdekat dengannya. Dia melihat, takut, putus asa, bingung. (He watched for a moment their upright faces closest to him. He looked, scared, desperate, confused.).

People who philosophize are people who think while being responsible. And the first responsibility is to his own conscience. Our character described by Iwan is as follows: How our character is still trying to survive in the transmigration village and trying to give meaning to the drought that occurred in the village, but it's useless; How at first he refused the Short Fat's generosity and how he built an ideal transmigrant area, the funds were obtained from the inheritance that Short Fat had given him. And so on, our character stays true to his conscience, not being tempted by the glare of city life. However, he has to live suffering or let's say in a situation of 'poverty' according to those who do not enjoy the essence of life. We hope that in real life, the dignitaries in this nation can maintain the sanctity of their conscience.

Iwan fever philosophizes. It seems he was influenced by Nietzsche. According to Nietzsche, courage is good. Nietzsche wanted constant challenges. Life must not be frozen, it must be dynamic. Likewise, the figure of our character in the Kering novel is like a traveller who longs for a sip of the water of life. Not earthly water. This brings our character to go on a journey to get various colors of life. Even our character dares to live alone in an arid transmigrant village. Dare to live alone in the Beggar's house accompanied by only dead dogs and continue his wanderings. Even more daring, he stays comfortable when everyone says he's crazy and hungry.

Iwan Simatupang's understanding of courage is not done without a sense 
of responsibility. For him, responsible courage is only possible to be built by strength, intelligence, and pride. The courage Iwan meant was total courage, daring to conquer fear and welcome death. Moreover he firmly stated that true courage does not require the testimony of anyone, not anyone else, not even God. True courage only manifests as a great passion for life, and a strong will to rise again, again and again. Philosophizing has penetrated Iwan, where according to Cogito Ergasum's philosophy, 'I think therefore I exist' - Rene Descartes' theory of rationalism. Iwan's awareness of human nature and its essence made him a radical person. Have a mindset that always digs something to its roots.

Iwan is also a social observer. He still presents a small group of people in the novel Kering. He told how the lives of small people who had no choice in their lives. Because of their helplessness in the arena of a very cruel life. Here's the snippet:

- Can their hometown accommodate them again?
- Who knows. But, if you have to be hungry anyway, it's better to experience it in your hometown.

- They can't explain, why. While they also know that dying of hunger in the transmigration area which is being hit by a long drought and dying of hunger in their hometown is the same thing as death. Return to hometown is what not fully accepted by them.

"Ashamed." A man snapped, sternfaced.

"Why should I be ashamed?" Our character snaps back.

Why? I am ashamed, because my first departure here was the departure of leaving my hometown for ever. Everything I own, I have sold. Or, I give it to my family. Then I was dispatched with a pretty lively celebration. Am I still able to go back there, in this state, with nothing? While what I'm chasing here is just poverty and life? What I'm after here is only death. No, I'd rather kill myself than endure the shame and ridicule that await me there.

This shows that humans sometimes have no other choice in life. Humans are more often entangled in the choices they do not want. Humans usually take decisions or shortcuts in dealing with their problems, because of their inability and blindness to the true understanding of life.

Iwan's style of irony and cynicism is expressed in the play Kering. This was said to satisfy his thirst to talk about the variety of life. In it Iwan stands as a critical citizen, daring to 
explore the inequality and weakness of the government bureaucracy. Like when Iwan explained the weakness of the transmigration employee who couldn't do anything because he was only ordered by his superiors."Say I want to imitate the attitude of the captain of the ship who was about to sink with his ship. For what a demonstration of valor like this? If for the sake of an establishment, what establishment?"

Iwan always tries to invite the reader not to do anything unwanted. But we must act according to the purity of conscience. As already explained, idealism requires courage (Prof. DR. N. Drijarkara S.J., Percikan Filsafat, Jakarta 1999, pp. 58-60).

Iwan's literary style which is the climax at least affects the hyperbole language style. The reader is invited to accept the emotions he wants to express until finally the reader is carried away by the flow of his ideas. We can see this in the sentence: "If not? No problem. He'll keep digging. If necessary, penetrate the earth's circle and arrive, for example, in the skin of the earth in Mexico or Texas."
Iwan Simatupang's closeness to Nietzsche's thoughts, turns out to have a similar story in his real life. Like Nietzsche, although physically weak, he was not content wander from one city to the other. Likewise, Iwan also traveled to several cities, including Sils Maria, Nizza, Monteno, Rome, Turin, and Genoa. Wherever Iwan goes, he is not at risk of renting a cheap room, the important thing is that there is enough room for writing and sleeping. It was enough for him.

Iwan also uses the language of personification - inanimate objects can act like human beings. He is also familiar with nature and enjoys being around. This is seen in the figure of our character.

"The sun reciprocates kindly through the chirping of birds and the first rays reflected by the spherical lens of its eye. Successively he called out good morning to anyone who met him that morning. To the shabby huts that are dry and brittle. To the furniture that has been scattered by the suffering that has been sent to evacuate... good morning to all, and if it is true that God exists... yes... also good morning to Him".

The presence of God in Iwan seemed doubtful. This phenomenon was caused by his disappointment with the very sad condition of the 
village and also not being helped by God's mercy, as was customary by his predecessors. Similar to Nietzsche, at the age of 18 , he had lost faith in God due to his life history. This seems to have inspired Iwan in conveying his aspirations.

However, not all of Nietzsche's ideas serve as guidelines for Iwan. We can see this from the following sentence:

"He ran, fast. Faster. He wanted to get to the city quickly, that city. His favorite city. The city that will become a living monument for the Beard and the Short Fat, 2 friends he once had in his life. A city that will inflate all their good natures, which in their lives they did not have time to practice. The city that will pass on the message to the times and generations in the future is only an internal matter between chance and intention, whether something is good or evil. In essence, they are the same. Both are good. Both great. For, man and all other creations, are truly great."

"They are the embodiment of weak, despicable human beings. They are people who enjoy their suffering, not because they can endure the suffering, but because of their suffering, they can expect the compassion of others. Therefore they are not suffering in the true sense. They just want to be seen in suffering so they think they deserve pity."

Iwan's awareness of human selfishness to beat others is highlighted in the situation of our character during college. Where our character is brought together in a meeting with his lecturers to be expelled from the university because he is being sued by a lecturer in the homeland department as a student who violates the rules that is applied at the University. Iwan describes how the conversation that took place between the scholars. Until finally Iwan sparked his aggravation. This is roughly what it says: "How strange it would be to meet so many intelligences at once..."

Nietzsche's life story also inspired Iwan Simatupang in his novel Kering. This thought can be seen in the character of our character that he wrote. Iwan seems to understand very well why the philosopher Nietzsche was admitted to the Mental Hospital because people in that time were not able to reach the thoughts that were poured out by Nietzsche. Iwan dedicates his empathy to Nietzsche's fate, through the figure of our character in the novel Kering. Nietzsche defended through the arguments of our character to the doctors of the Mental Hospital. 
Apart from being serious, Iwan also has a pretty good sense of humor. In the novel Kering, p. 45. It reads as follows: "I don't want to insult the doctor at all. However, this does not reduce my will to immediately leave this section. This hospital. Because who knows, once I left the mental illness clinic, then $I$ will be put in another section again. You know, the opinion of the gentlemen are very strong. I must be sick. Who knows, the gentlemen will have heart to put me in the maternity clinic..."

Another side of life is also exposed in the novel Kering. Iwan has a sensitivity to people's behavior, making it into a living story. How is the behavior of people who become knowing and judgmental? Iwan explores it interestingly by presenting nuances of humor and satire on the sidelines of the scenes he wrote.

- The chorus of many horns at once is getting louder.

- Very moving, shouted another car driver.

- His face is red wet with sweat

- Why isn't your flirting going on elsewhere, doesn't hinder this many people.

- Gay, shouted the other driver.
- The drivers of several trucks in their convoy laughed.

- Someone's whistling. Some applaud. A foreign car driver, with a CD plate, was busy taking photos.

The nuance of the presence of a car driver with a CD plate is not just a decoration in his writing, but the meaning he wants to convey is, how foreign nations in Indonesia are always able to earn more than their own people whose mindset is slow, usually just cursing and laughing at other people.

According to the philosopher Nicolas Alexandrovitch Berdyaev, society is the infinite power of personality. In such a paradoxical situation, humans on the one hand experience suffering, on the other hand also limit their freedom. This is clearly illustrated in the story of our character and the Fat one who is disturbed by releasing their longing. The community does not want to compromise, whether they both release their longing or what. People do not want to be disturbed by their interests.

Iwan seems to have lived the thoughts of several philosophers. It's proven from the sentence that present in "Kering" either implicitly 
or explicitly. As quoted from the philosopher Berdyaev: "... modern technological civilization is a changing view, human appreciation of time. Modern human look more forward, for him them activities are projected into the future. Modern technological civilization has changed the rhythm of human life..." (Existentialism Philosophy, p. 69).

It is how Iwan lived the words until the end of his life. The woman presented by Iwan in 'Kering' is a beautiful woman who can only give sexual satisfaction to men. Selling beauty and coquettishness for money, or crying when the person who helped him died.

Iwan's understanding of death was also greatly influenced by Karl Jaspers who said: "What is death, nobody knows. What certain is that it will end existence at a predetermined time. Morscerta, hora incerta. That death is certain, will never be denied when death arrives. What is death? That's what we don't know for sure. After all, death is the ultimate limit to existence."

The figure of our character in 'Kering' is described by Iwan as a person who is so aggressive in hurting himself. Being who are confused with themselves, or people who are never silent with their thoughts. Iwan also feels lonely in his search for ideas that he wants to pour. He departs from his contemplations in his adventures. This is described in the expression of compassion, love, brotherhood in the form of tears. Iwan often overcomes the climax of a problem with sentimental feelings.

In his drift with modern philosophy, we still see his Eastern philosophy which has become a myth in our lives. As this anecdote says: "His food and drink needs are solved solely based on social principles that are common in every democratic society. Who works, he eats. His food is balanced with his work."

Kering Novel on pages 136-141, can be seen the philosophers who are attached to Iwan's heart. As when he alludes to the story of Zarathustra, belong to the philosopher Nietzsche who preached to the masses. Then the story of the adventures of Berdyaev who was thrown out 
because of the ideology he embraced and touted.

In Iwan's odyssey through the novels 'Kering', we can see that in the end, he realized human limitations. As Nietzsche said: "Know yourself. Don't want anything beyond your means. Those who want something above their ability, do something that contains disgusting falsehoods. Everyone has their place in this life, according to their respective abilities. Therefore, all human endeavors must be adjusted to the limits of their abilities. Whoever wants to climb a height must use his own feet."

At the end of the story "Kering", Iwan admits his limitations. This is implied when our character builds a city that he thinks is ideal and tries to create a new society. In the end, he realized that his actions only led to contradictions (can be seen on pages 166-167). Although Iwan has acknowledged the contradictions he has made, he still wants to continue to do so by the dialectical journey of his life. He wants to continue to be a creator human. A man who is not afraid of fear and suffering. According to him, the dialectic of the silence of mind is very much needed by people like him who like to contemplate and ask questions about life or maybe about death.

\section{Conclusion}

From the results of the above review, at least it can be concluded. Iwan, in channelling his ideas and thoughts is by the understanding of the philosophers he admires, namely existentialist philosophers. Iwan can also be called a nihilist. He negates all old values and confirms standard values. He tried to overcome something he felt was an obstacle in the creation of his writing. The flow of thoughts he emits in a firm, yet artistic form. He can be called a vitalist because of his extraordinary passion for life. In addition, Iwan loves adventures that are free and dangerous inventing his thoughts. This is most evident in the novel 'Kering'. He ignores the rules, neither in his life nor in formulating his thoughts. If people want to characterize the nature of his mind and wisdom, it is fierce, like a sailboat hit by the waves of the ocean. 
Iwan Simatupang's "Kering" is not only in a physical sense but is more contemplative in nature. With the adventures carried out, he describes how the actors are afflicted with psychological, spiritual, ideas, and ready to be swallowed by termites so that it becomes pathetic.

\section{References}

Anshari, H. Endang Saifuddin. (2012). Ilmu Filsafat dan Agama. Jakarta: Bina Ilmu.

Alisyahbana, S. Takdir. (2016). Pembimbing ke Filsafat. Jakarta: Dian Rakyat.

Castel, Alburey. (1999). An Introction to Modern Philosophy : In Six Philosophical Problems: New York Drijarkara S.J.. (2019). Percikan Filsafat. Jakarta: Pembangunan.
Hadiwijoyo, Harun. (1997). Sari Sejarah Filsafat Barat I. Yogyakarta: Kanisius.

Narsrum, M. (1989). Dari Mana, Di Mana, Ke Mana. Jakarta: Bulan Bintang.

Jongeneel, J.A.B.. (1997). Misteri Kepercayaan dan Ilmu Pengetahuan. Jakarta: BPK Gunung Mulia. Soemardjo, Jacob. (1999). Memahami Kesusastraan. Bandung: Alumni. Jassin, H.B. (2009). Nietzsche Zarathustra. Jakarta: PT Buku Seru. Hiplunudin, Agus. (2005). Filsafat Eksistensialisme. Yogyakarta: Graha Ilmu.

Sartre, Jean-Paul. (2014). Filsafat Eksistensialisme Jean- Paul Sartre. Yogyakarta: Kanisius.

Hamka, Buya. (2015). Falsafah Ketuhanan. Yogyakarta: Republika. Martin Op, Vincent. (2016). Filsafat Eksistensialisme (Kierkegaard,Sartre, Camus). Yogyakarta: Pustaka Pelajar.

Rosi Sianipar Alumni ISBI Bandung, IKJ; Dosen Program Studi Fotografi dan Film Fakultas IImu Seni dan Sastra Universitas Pasundan Bandung 